\title{
The Development of Specific Responses of the Exocrine Pancreas to Pancreozymin and Secretin Stimulation in Newborn Infants
}

\author{
G. Zoppi ${ }^{[15]}$, G. Andreotti, F. Pajno-Ferrara, P. Bellini ${ }^{[14]}$, and D. Gaburro \\ Clinica Pediatrica dell'Università di Padova---Sede di Verona, Istituto di Puericultura dell'Università di Ferrara, \\ Unità di Statistica del Policlinico Borgo Roma, Verona, Italy
}

\begin{abstract}
Extract
The pancreatic secretion rates of fluid, protein, $\mathrm{Na}^{+}, \mathrm{K}^{+}, \mathrm{Ca}^{++}$, and $\mathrm{HCO}_{3}{ }^{-}$before and after pancreozymin and secretin stimulations have been studied in 25 premature and 12 full term newborn infants. The secretion rates are (with few exceptions) higher in premature than in full term newborn infants. In both groups of subjects at birth the pancreozymin and the secretin stimulations yield an increment of pancreatic secretion rates; differences between the responses to pancreozymin and secretin have been observed but are statistically not significant; a statistically significant differentiated response to each of the two hormones appeared only in premature newborn infants at 1 month of age.
\end{abstract}

\section{Speculation}

In premature and full term newborn infants the exocrine pancreas is functionally unable to distinguish pancreozymin from secretin at birth, but it is able to do so at 1 week of age. A week of adaptation to extrauterine life seems to be necessary in order to obtain a response to hormonal stimulation qualitatively similar to, although quantitatively lower than, that of older infants and children.

\section{Introduction}

In a previous study on the pancreatic production of protein and electrolytes in infants and children we demonstrated [10] that in healthy study subjects aged between 9 months and 13 years the secretion rates of sodium and bicarbonate are higher after secretin stimulation, those of calcium, magnesium and protein are higher after pancreozymin and those of duodenal fluid and potassium are practically the same after stimulation by each of the two hormones. It therefore appears that, as in adults [2, 7], the exocrine pancreas responds specifically to pancreozymin and secretin in healthy infants and children [10]. Whether the time of onset of this specific response to hormonal stimulation is at birth or some time after birth was then not investigated and is at that time obscure. During the last few years, after devising a method suitable for studying the pancreatic function in neonates, we determined quantitatively the secretion of enzymes at birth and during the first few weeks of life [8]. Using the same method we determined the protein and electrolyte secretions before and after stimulation with pancreozymin and secretin in premature and full term newborn infants in an attempt to 
find out the time of onset of specific response of the pancreas to hormonal stimulations.

\section{Materials and Methods}

\section{Subjects Studied}

We studied 25 premature infants (18 females and 7 males) of gestational (postmenstrual) ages between 32 and 34 weeks and a birthweight ranging between 1.8 and $2.4 \mathrm{~kg}$ (mean $=2.32 \mathrm{~kg}$ ) and 12 full term newborn infants ( 8 females and 3 males) with a birthweight between 3.4 and $4.2 \mathrm{~kg}$ (mean $=3.84 \mathrm{~kg}$ ). The study subjects were considered healthy as none of them presented signs of neurologic and respiratory disturbance and all had an Apgar score of 10. The study subjects were tested 2-6 $\mathrm{hr}$ after birth before the first feeding, during the second day, at 1 week, and (only premature newborn infants) at 1 month of age. Permission for studying these subjects was obtained from the parents after a full explanation of the procedure. During the study all of the patients were fed the same commercial infant formula [11]. No disturbance was observed during or after the pancreatic function test in any patients studied.

\section{Methods}

Tubes, and techniques of duodenal intubation and sampling were exactly the same as in the previous study [8]. During the test we made particular efforts to exclude functionally the duodenum from the stomach and the jejunum in order to avoid contamination or loss of duodenal fluid. The hormones used were pancreozymin and secretin Boots given in a dosage of 2 I.U. $/ \mathrm{kg}$, body wt. Duodenal fluid, protein, $\mathrm{Na}^{+}, \mathrm{K}^{+}$, $\mathrm{Ca}++$, and $\mathrm{HCO}_{3}{ }^{-}$were determined as in previous studies $[9,10]$. The results are expressed as secretion rates per kilogram of body weight per minute before and after each single hormonal stimulation.

Statistical evaluations of the results have been done in two steps according to Morrison's profile analysis technique for several groups [5]: the first one consists in calculating whether the mean values of each examined variable before hormonal stimulation, after pancreozymin and after secretin at various times of observation (mean profiles) are parallel (parallelism test), eventually on the same level (equal treatment levels test) and again superimposed to a straight line parallel to the abscissa (equal response effects test). The second step has been applied only in those cases where the mean profiles were not parallel; it consists in using the parametric $p$ univariate analysis of variance ( $F$ test) with simultaneous confidence intervals according to the procedure of Scheffé [6] for sampling units normally distributed, and a nonparametric oneway analysis of variance ( $H$ test according to the procedure of Kruskal and Wallis [4]) for sampling units not normally distributed and having too large individual variations (Bartlett test [1]).

\section{Results}

In Table I are reported the secretion rates of fluid, protein, and electrolytes before and after hormonal stimulations in the premature newborn infants. At birth, the secretion rates of all examined components of duodenal juice show a clear increase after hormonal stimulation and this increase is of the same extent after either pancreozymin or secretin. Beginning from the second day and more clearly at 1 week and 1 month of age the secretion rates of fluid, $\mathrm{Na}+, \mathrm{K}+$, and $\mathrm{HCO}_{3}-$ tend to be higher after secretin, whereas those of protein and $\mathrm{Ca}^{+}+$tend to be higher after pancreozymin. All values are considerably lower than those observed [10] in infants and children between 9 months and 13 years of age, here reported for comparison purposes.

In Table II are reported the secretion rates of fluid, protein, and electrolytes of full term newborn infants. Observations similar to those made for premature newborn infants also apply to the full term newborn infants in whom the secretion rates expressed per kilogram of body weight per minute are in several cases lower than in the former.

\section{Statistical Evaluation}

In the premature newborn infants the test of parallelism of the mean profiles (Fig. 1) according to the method of Morrison [5] yields a statistical significance (Table III), i.e., the profiles are not parallel except in the case of fluid. For such a reason the equal treatment levels test and the equal response effects test have not been applied and the equality of the response has been tested separately by a $p$ univariate analysis of variance with simultaneous confidence intervals according to the method of Scheffé [6] and by a one-way analysis of variance according to the method of Kruskal and Wallis [4]. The results (Table IV) show that in premature newborn infants the differences of the mean values obtained before hormonal stimulation (A) and 
Table I. Pancreatic fluid, protein, and electrolyte secretion rates in premature infants and in children before and after pancreozymin $(\mathrm{P})$ and secretin $(\mathrm{S})$ stimulations (mean $\pm \mathrm{sD} / \mathrm{min} / \mathrm{kg}$, body $\mathrm{wt})$

\begin{tabular}{|c|c|c|c|c|c|c|}
\hline \multirow{2}{*}{ Variables } & & \multicolumn{5}{|c|}{ Profile analysis } \\
\hline & & Birth & 2nd Day & $1 \mathrm{Week}$ & 1 Month & Children $^{1}$ \\
\hline \multirow{3}{*}{ Fluid, $\mu 1 / \mathrm{min} / \mathrm{kg}$} & Before stimulations & $7.9 \pm 4.8$ & $9.6 \pm 4.7$ & $13.9 \pm 10.6$ & $15.2 \pm 14.6$ & $35.3 \pm 25.5$ \\
\hline & After $P$ & $9.3 \pm 5.4$ & $8.3 \pm 3.9$ & $18.2 \pm 13.2$ & $23.5 \pm 18.5$ & $69.3 \pm 27.7$ \\
\hline & After S & $9.9 \pm 9.0$ & $13.3 \pm 5.1$ & $19.8 \pm 13.5$ & $28.9 \pm 16.1$ & $86.1 \pm 47.9$ \\
\hline \multirow[t]{3}{*}{ Protein, $\mu \mathrm{g} / \mathrm{min} / \mathrm{kg}$} & Before stimulations & $121.1 \pm 40.8$ & $116.6 \pm 20.9$ & $132.8 \pm 60.3$ & $154.5 \pm 59.4$ & \\
\hline & After $\mathrm{P}$ & $301.2 \pm 86.8$ & $173.4 \pm 52.9$ & $271.2 \pm 298.4$ & $295.3 \pm 147.5$ & $559 \pm 107$ \\
\hline & After $S$ & $305.6 \pm 90.2$ & $128.5 \pm 32.3$ & $152.3 \pm 130.4$ & $159.9 \pm 51.1$ & $262 \pm 143$ \\
\hline \multirow[t]{3}{*}{$\mathrm{Na}^{+}, \mu \mathrm{eq} / \mathrm{min} / \mathrm{kg}$} & Before stimulations & $0.83 \pm 0.32$ & $0.69 \pm 0.31$ & $1.66 \pm 1.08$ & $1.42 \pm 1.12$ & \\
\hline & After P & $1.99 \pm 1.05$ & $1.46 \pm 0.32$ & $3.42 \pm 1.9$ & $3.22 \pm 2.08$ & $106 \pm 43$ \\
\hline & After $S$ & $2.02 \pm 1.42$ & $1.73 \pm 0.48$ & $3.76 \pm 1.74$ & $4.05 \pm 1.76$ & $131 \pm 78$ \\
\hline \multirow[t]{3}{*}{$\mathrm{K}^{+}, \mu \mathrm{eq} / \mathrm{min} / \mathrm{kg}$} & Before stimulations & $0.02 \pm 0.013$ & $0.025 \pm 0.012$ & $0.062 \pm 0.084$ & $0.052 \pm 0.031$ & \\
\hline & After $P$ & $0.074 \pm 0.039$ & $0.053 \pm 0.032$ & $0.124 \pm 0.105$ & $0.078 \pm 0.034$ & $4.2 \pm 1.9$ \\
\hline & After $\mathrm{S}$ & $0.085 \pm 0.04$ & $0.063 \pm 0.031$ & $0.109 \pm 0.073$ & $0.110 \pm 0.050$ & $3.9 \pm 1.6$ \\
\hline \multirow{3}{*}{$\mathrm{Ca}^{++}, \mu \mathrm{g} / \mathrm{min} / \mathrm{kg}$} & Before stimulations & $0.32 \pm 0.28$ & $0.22 \pm 0.20$ & $1.09 \pm 1.22$ & $0.85 \pm 0.50$ & \\
\hline & After P & $0.67 \pm 0.32$ & $0.54 \pm 0.33$ & $1.80 \pm 1.45$ & $1.95 \pm 1.21$ & $1.8 \pm 0.7$ \\
\hline & After S & $0.67 \pm 0.31$ & $0.49 \pm 0.27$ & $1.18 \pm 0.90$ & $1.19 \pm 0.58$ & $0.6 \pm 0.4$ \\
\hline \multirow[t]{3}{*}{$\mathrm{HCO}_{3}^{-}, \mu \mathrm{eq} / \mathrm{min} / \mathrm{kg}$} & Before stimulations & $0.012 \pm 0.008$ & $\overline{0}$ & $0.022 \pm 0.31$ & $0.07 \pm 0.18$ & \\
\hline & After $P$ & $0.186 \pm 0.119$ & $0.18 \pm 0.23$ & $0.49 \pm 0.32$ & $0.22 \pm 0.12$ & $2 \pm 0.9$ \\
\hline & After $s$ & $0.28 \pm 0.16$ & $0.41 \pm 0.28$ & $0.62 \pm 0.29$ & $0.63 \pm 0.26$ & $5.5 \pm 2.4$ \\
\hline
\end{tabular}

1 Values reported from Reference 3.

Table II. Pancreatic fluid, protein, and electrolyte secretion rates in full term infants and in children before and after pancreozymin $(\mathrm{P})$ and $\operatorname{secretin}(\mathrm{S})$ stimulations (mean $\pm \mathrm{sD} / \mathrm{min} / \mathrm{kg}$, body $\mathrm{wt}$ )

\begin{tabular}{|c|c|c|c|c|c|}
\hline \multirow{2}{*}{ Variables } & & \multicolumn{4}{|c|}{ Profile analysis } \\
\hline & & Birth & 2nd Day & 1 Week & Children ${ }^{1}$ \\
\hline \multirow[t]{3}{*}{ Fluid, $\mu \mathrm{l} / \mathrm{min} / \mathrm{kg}$} & Before stimulations & $6.9 \pm 5.5$ & $8.2 \pm 4.3$ & $8.3 \pm 3.7$ & $35.3 \pm 25.5$ \\
\hline & After $P$ & $8.3 \pm 5.3$ & $8.6 \pm 4.8$ & $8.4 \pm 5.9$ & $69.3 \pm 27.7$ \\
\hline & After $S$ & $8.0 \pm 7.2$ & $8.5 \pm 6.8$ & $11.4 \pm 6.6$ & $86.1 \pm 47.9$ \\
\hline \multirow[t]{3}{*}{ Protein, $\mu \mathrm{g} / \mathrm{min} / \mathrm{kg}$} & Before stimulations & $90.6 \pm 17.3$ & $131.9 \pm 27.5$ & $137.6 \pm 51.6$ & \\
\hline & After P & $163.1 \pm 54.4$ & $264.4 \pm 103.5$ & $334.8 \pm 188.9$ & $559 \pm 107$ \\
\hline & After S & $165.6 \pm 58.2$ & $234.5 \pm 65.3$ & $140.9 \pm 62.0$ & $262 \pm 143$ \\
\hline \multirow[t]{3}{*}{$\mathrm{Na}^{+}, \mu \mathrm{eq} / \mathrm{min} / \mathrm{kg}$} & Before stimulations & $1.32 \pm 0.72$ & $2.02 \pm 1.91$ & $1.39 \pm 0.43$ & \\
\hline & After $P$ & $2.37 \pm 1.16$ & $2.39 \pm 1.71$ & $\mathrm{I} .31 \pm 0.39$ & $106 \pm 43$ \\
\hline & After $S$ & $2.77 \pm 1.82$ & $2.62 \pm 1.48$ & $1.87 \pm 0.94$ & $131 \pm 78$ \\
\hline \multirow[t]{3}{*}{$\mathrm{K}^{+}, \mu \mathrm{eq} / \mathrm{min} / \mathrm{kg}$} & Before stimulations & $0.036 \pm 0.018$ & $0.043 \pm 0.046$ & $0.035 \pm 0.025$ & \\
\hline & After P & $0.058 \pm 0.2 \mathrm{I}$ & $0.111 \pm 0.073$ & $0.148 \pm 0.28$ & $4.2 \pm 1.9$ \\
\hline & After $S$ & $0.081 \pm 0.064$ & $0.101 \pm 0.55$ & $0.112 \pm 0.043$ & $3.9 \pm 1.6$ \\
\hline \multirow[t]{3}{*}{$\mathrm{Ca}^{++}, \mu \mathrm{g} / \mathrm{min} / \mathrm{kg}$} & Before stimulations & $0.73 \pm 0.33$ & $0.97 \pm 0.44$ & $1.13 \pm 0.48$ & \\
\hline & After $P$ & $1.59 \pm 0.91$ & $1.92 \pm 1.82$ & $2.05 \pm 1.61$ & $1.8 \pm 0.7$ \\
\hline & After $S$ & $1.67 \pm 0.96$ & $1.37 \pm 1.10$ & $1.36 \pm 0.93$ & $0.6 \pm 0.4$ \\
\hline
\end{tabular}

1 Values reported from Reference 3.

after pancreozymin (B) and secretin (C) are significant with few exceptions; the differences between the mean values obtained after pancreozymin (B) and those obtained after secretin (C) begin to be statistically significant only at 1 month of age except when the variable is fluid or $\mathrm{Na}^{+}$, neither of which is significant.

In the full term newborn infants the mean profiles do not show any statistically significant difference except in the case of protein; i.e., the profiles are parallel and overlap (Fig. 1 and Table III). For this reason, in this case, a $p$ univariate analysis of variance was not done since the mean values at various times may be assumed to be statistically not different.

\section{Discussion}

From the results reported above it may be seen that in both the premature and full term newborn infants at 

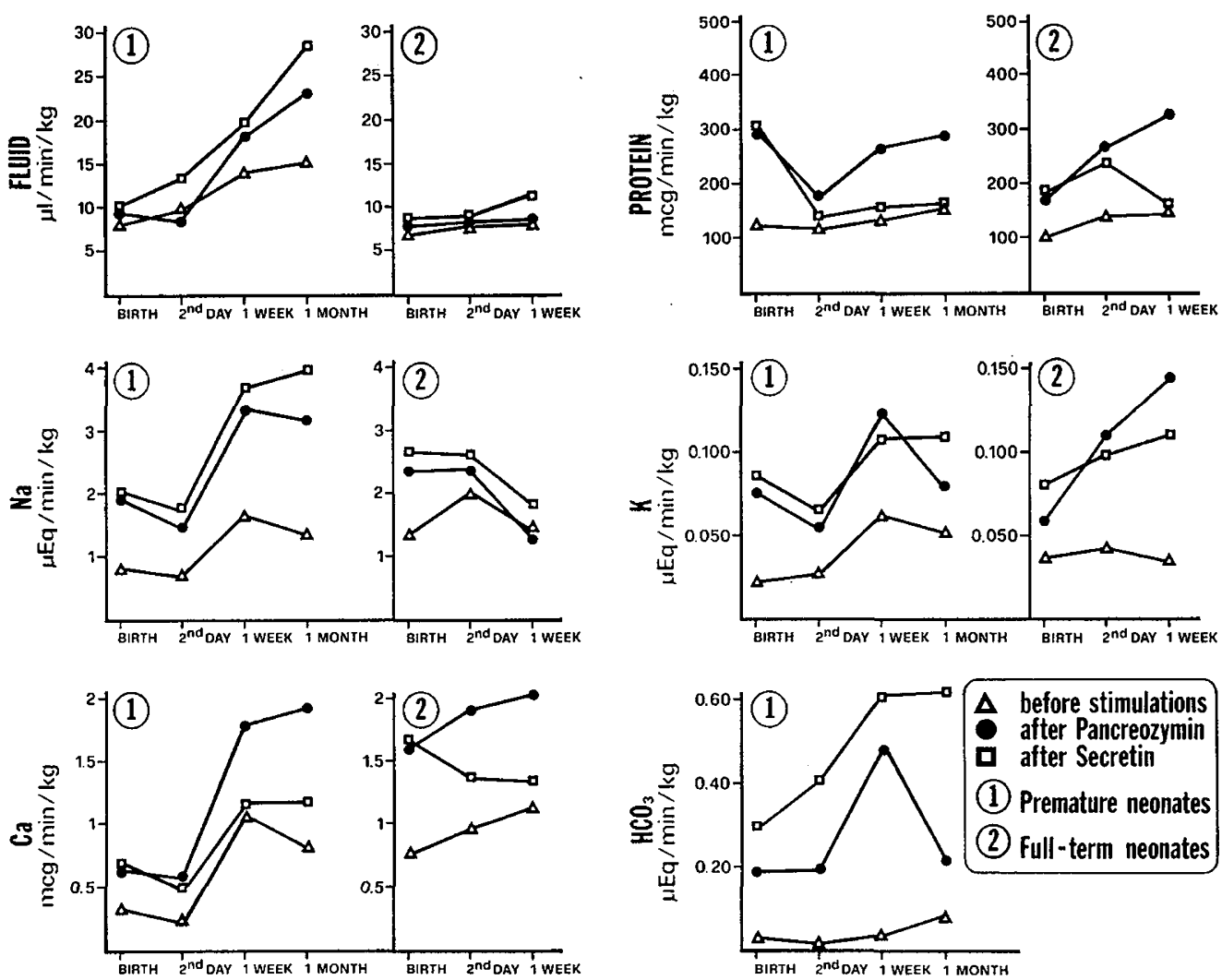

liig. 1. Profiles of the mean values of pancreatic fluid, protein, and electrolyte secretion rates in premature and full term newborn infants at various ages.

Table III. Profile analysis of variables (fluid, protein, $\mathrm{Na}^{+}, \mathrm{K}^{+}, \mathrm{Ca}^{++}$secretion before and after hormonal stimulation) in premature and full term newborn infants ${ }^{1}$

\begin{tabular}{|c|c|c|c|c|c|c|c|c|c|c|c|}
\hline \multirow{4}{*}{ Variables } & \multirow{4}{*}{ Sample groups } & \multicolumn{10}{|c|}{ Profile analysis } \\
\hline & & \multicolumn{2}{|c|}{ Parallelism test ${ }^{2}$} & \multicolumn{2}{|c|}{$\begin{array}{l}\text { Equal treatment } \\
\text { levels test }\end{array}$} & \multicolumn{6}{|c|}{ Equal response effects test (at various times) ${ }^{4}$} \\
\hline & & \multirow{2}{*}{ Level } & \multirow{2}{*}{ Significant } & \multirow{2}{*}{ Level } & \multirow{2}{*}{ Significant } & \multicolumn{2}{|r|}{ A } & \multicolumn{2}{|r|}{ B } & \multicolumn{2}{|r|}{$\mathrm{c}$} \\
\hline & & & & & & Level & Significance & Level & Significance & Level & Significance \\
\hline \multirow{2}{*}{ Fluid } & Premature & 6.34 & n.s. & 4.75 & $P<0.05$ & 1.71 & n.s. & 5.60 & $P<0.05$ & 5.07 & $P<0.05$ \\
\hline & Full term & 0.31 & n.s. & 0.76 & n.s. & 0.04 & n.s. & 0.07 & n.s. & 0.23 & n.s. \\
\hline \multirow[t]{2}{*}{ Protein } & Premature & 64.69 & $P<0.01$ & & & & & & & & \\
\hline & Full term & 8.25 & n.s. & 6.68 & $P<0.01$ & 12.47 & $P<0.001$ & 2.17 & n.s. & 13.57 & $P<0.001$ \\
\hline \multirow[t]{2}{*}{$\mathrm{Na}^{+}$} & Premature & 22.76 & $P<0.01$ & & & & & & & & \\
\hline & Full term & 4.94 & n.s. & 1.81 & n.s. & 0.32 & n.s. & 3.34 & n.s. & 1.44 & n.s. \\
\hline \multirow[t]{2}{*}{$\mathrm{K}^{+}$} & Premature & 18.37 & $P<0.01$ & & & & & & & & \\
\hline & Full term & 2.38 & n.s. & 2.22 & n.s. & 0.04 & n.s. & 2.46 & n.s. & 1.03 & n.s. \\
\hline \multirow[t]{2}{*}{$\mathrm{Ca}^{++}$} & Premature & 16.36 & $P<0.05$ & & & & & & & & \\
\hline & Full term & 4.74 & n.s. & 2.43 & n.s. & 4.02 & n.s. & 0.33 & n.s. & 1.2 & n.s. \\
\hline
\end{tabular}

${ }^{1}$ n.s.: Not significant; A : before hormonal stimulation; B : after pancreozymin stimulation; C: after secretin stimulation. A, B, and C are considered at the various times of observation, i.e., A (before hormonal stimulation) at birth, at second day and at 1 week of age, etc.

${ }^{2}$ One-way multivariate analysis of variance with generalization $T^{2}$-Hotelling [3].

${ }^{3} F=(N-K / K-1) / \mathrm{SST} / \mathrm{SSE}$, where SST = deviation of treatment $(K)$ and SSE $=$ deviation of errors.

${ }^{4} T^{2}=N \bar{y} S_{y^{1}}^{-} \bar{y}\left(T^{2}\right.$ statistic for the single-sample repeated measurements). 
Table IV. Parametric (F) and nonparametric (H) one-way analysis of variance for variables with nonparallel mean profiles in premature newborn infants ${ }^{1}$

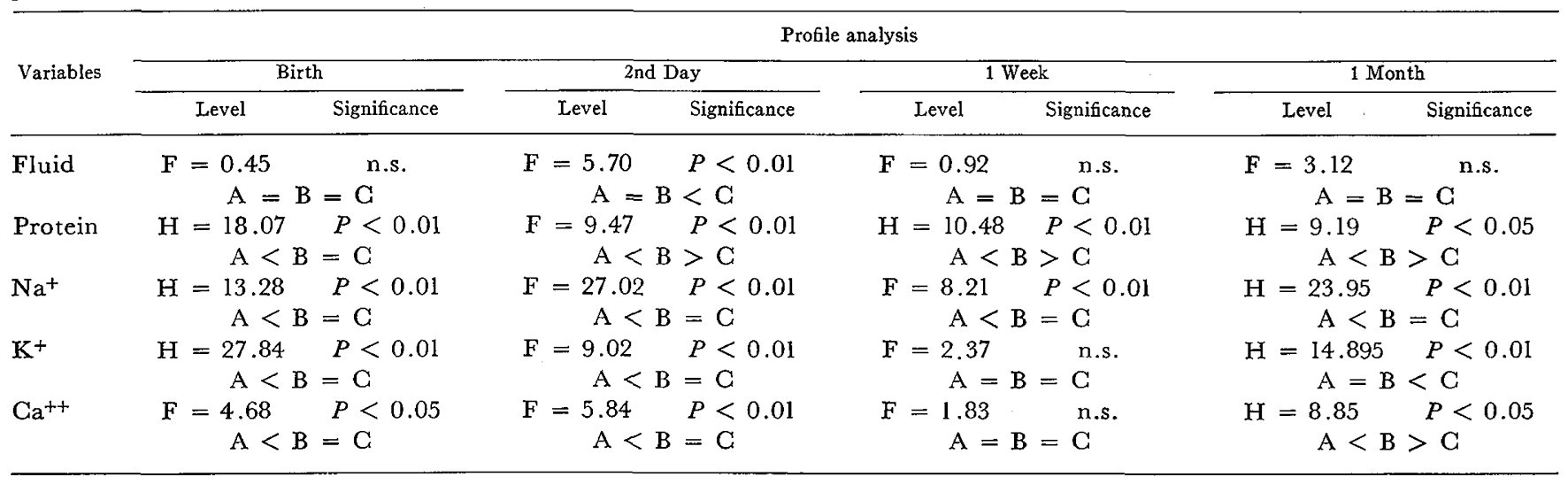

1 A : Before stimulations; B : after pancreozymin stimulation; C: after secretin stimulation; n.s. : not significant.

birth the exocrine pancreas appears to respond in the same manner and degree to either pancreozymin or secretin, whereas, after 1 week of life, the response to each of these hormones begins to appear specific and similar to (although lower than) that observed in older infants and children [10]. In other words, the exocrine pancreas in both premature and full term newborn infants begins to distinguish functionally pancreozymin from secretin only after 1 week of life. One would argue that this pattern depends upon the hormones used (Boots) not being absolutely pure. But were it so, it would be difficult to explain why a clear difference between the response to the same hormones appears after I week of life.

By analyzing the secretion patterns before stimulation, after pancreozymin and secretin stimulation longitudinally at the various period of observation (profile of secretion, Fig. 1), one may observe that a constant increase of the response before and after hormonal stimulation occurs in the case of all variables examined (except on the second day of life in premature infants and in a few other cases), so that clear differences between these responses (although statistically significant only in the premature newborn infants at 1 month of life) may be seen in both premature and full term newborn infants from the second day of life.

Finally, by comparing the results obtained in both groups of subjects studied, one may observe that the secretion rates tend (with few exception) to be higher in premature than in full term newborn infants. This observation is in accordance with the results obtained in the study of enzyme production in patients of the same ages and seems to indicate a more active exocrine pancreas function in premature than in full term newborn infants [8].

\section{Summary}

The pancreatic secretion rates of fluid, protein, and electrolytes after pancreozymin and secretin stimulation are higher (with few exception) in premature than in full term newborn infants. An increment of pancreatic secretion rates after hormonal stimulation is present at birth in both groups of patients, but a statistically significant differentiated response to the two hormonal stimulations has been observed only in premature newborn infants at 1 month of life.

\section{References and Notes}

1. Bartletr, M. S.: Properties of sufficience and statistical tests. Proc. Roy. Soc. Ser. A, 160: 268 (1937).

2. Drexling, D.: Mechanism of pancreatic exocrine secretion. Amer. J. Gastroenterol., 52: 17 (1969).

3. Hsu, P. L.: Notes on Hotelling's generalized $T^{2}$. Ann. Mathem. Stat., 9: 231 (1938).

4. Kruskal, W. H., and Wallis, W. A.: Use of rank in onecriterion variance analysis. J. Amer. Statist. Ass., 47: 583 (1952).

5. Morrison, D. F.: Multivariate Statistical Methods, p. 186. (McGraw-Hill, New York, 1967).

6. SHEFFE, H.: A method for judging all contrast in the analysis of variance. Biometrika, 40:87 (1953).

7. Wormsley, K. G.: A comparison of the response to secretin, pancreozymin and a combination of these hormones in man. Scand. J. Gastroenterol. 4: 413 (1969).

8. Zoppi, G., Andreottri, G., Pajno-Ferrara, F., NJai, D. M., and Gaburro, D.: The exocrine pancreas function in premature and full term neonates. Pediat. Res., 6: 880 (1972).

9. Zoppi, G., Hitzig, W. H., Shmerling, D. H., Plüss, H., Hadorn, B., and Prader, A.: Protein content and pancreatic enzyme activities of duodenal juice in normal children and 
in children with exocrine pancreatic insufficiency. Helv. Paediat. Acta, 23: 577 (1968).

10. Zoppi, G., Shmerling, D. H., Gaburro, D., And Prader, A.: The electrolyte and protein contents and outputs in duodenal juice after pancreozymin and secretin stimulation in normal children and in patients with cystic fibrosis. Acta Paediat. Scand., 59: 692 (1970).

11. Similac, Abbott.

12. This research was supported by Grant no. 70.00967 .04 of the Consiglio Nazionale delle Ricerche.
13. Reported in part at the Annual Meeting of European Society for Pediatric Gastroenterology, Hamburg (West Germany), September 8-9, 1972.

14. Dr. P. Bellini is a Research Fellow in Statistics of the Consiglio Nazionale delle Ricerche, Grant no. 202.439, December 2, 1970.

15. Requests for reprints should be addressed to: G. ZopPI, M.D., Clinica Pediatrica dell'Università, Policlinico Borgo Roma, 37100 Verona, Italy.

16. Accepted for publication December 13, 1972. 